\title{
The Impact Of Inventory Valuation Methods On Corporate Financial Reports
}

\author{
A. Bruce Caster, Ph.D., CPA, CGMA, Siena College, USA \\ Wanda K. Causseaux, DBA, CMA, Siena College, USA
}

\begin{abstract}
Business students are generally introduced to LIFO and FIFO in their first accounting course. However, that introduction generally focuses exclusively on computing ending inventory and cost of goods sold. Students are rarely challenged to compute or analyze the impacts of LIFO and FIFO on the income statement, balance sheet, or cash flow statement. This paper presents a hypothetical case designed to provide a framework within which students can compute, analyze, and discuss the financial statement impacts and economic impacts of choosing one or the other of these accounting methods. The questions in this case also address the effects of this choice on financial indicators like liquidity ratios, the impacts of each method on quality of earnings, and the potential impacts of IFRS convergence on companies that are currently using LIFO.
\end{abstract}

One important feature of this case is its adaptability to support a variety of learning outcomes in different courses. This flexibility results from making the questions posed in the case as independent of each other as possible. That independence allows a professor to select only the questions that support the learning outcomes for that professor's specific course. The teaching notes discuss in detail possible course applications and uses of this case.

Keywords: FIFO; LIFO; Cash Flow; Quality of Earnings; IFRS Convergence

\section{INTRODUCTION}

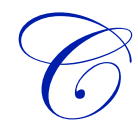
hoosing between LIFO and FIFO for financial reporting purposes is much more complicated that it would first appear. That choice has both financial reporting implications and also tax implications. It affects income, cash flows, and financial indicators like liquidity and profitability ratios. Business students are generally introduced to LIFO and FIFO in their first accounting course. However, that introduction generally focuses exclusively on computing ending inventory and cost of goods sold. The purpose of this case is to provide a framework within which students can both examine the computational aspects of using FIFO versus LIFO and also analyze and discuss the impact of that choice on the information communicated in the financial statements. The case also provides opportunities for in-class discussions of topics like quality of earnings and the potential consequences of IFRS convergence.

\section{FACTS OF THE CASE}

\section{F Company}

F Company is a retailing company that began operations on January 1, 20X1, when the owner invested $\$ 4,000$ of inventory (100 units with a cost and a fair value of $\$ 40$ each) in exchange for 4,000 shares of F Company's $\$ 1$ par value common stock. F Company immediately purchased a $\$ 15,000$ machine and gave a five-year, $10 \%$, promissory note in payment. The machine has an estimated life of five years, and it will be depreciated using the straight-line method assuming zero salvage value. The note requires five annual year-end payments of interest only. The entire $\$ 15,000$ principal amount will be due in one single payment on January 1, $20 \mathrm{X} 6$.

During the years $20 \mathrm{X} 1$ to $20 \mathrm{X} 5$, F Company bought 500 units of inventory each year and sold 500 units of inventory each year. Details of these transactions are shown in Table 1. 
Table 1. Details of Inventory Transactions for 20X1 to 20X5

\begin{tabular}{l|r|r|r|r|r}
\hline Inventory Information (units) & $\mathbf{2 0 X 1}$ & $\mathbf{2 0 X 2}$ & $\mathbf{2 0 X 3}$ & $\mathbf{2 0 X 4}$ & $\mathbf{2 0 X 5}$ \\
\hline Beginning Inventory (units) & 100 & 100 & 100 & 100 & 100 \\
\hline Units Purchased (units) & 500 & 500 & 500 & 500 & 500 \\
\hline Units Sold (units) & $(500)$ & $(500)$ & $(500)$ & $(500)$ & $(500)$ \\
\hline Ending Inventory (units) & 100 & 100 & 100 & 100 & 100 \\
\hline & \multicolumn{5}{|c|}{} \\
Selling prices and purchase costs & $\mathbf{2 0 X 1}$ & $\mathbf{2 0 X 2}$ & $\mathbf{2 0 X 3}$ & $\mathbf{2 0 X 4}$ & $\mathbf{2 0 X 5}$ \\
\hline Selling price (per unit) & $\$ 80$ & $\$ 90$ & $\$ 100$ & $\$ 110$ & $\$ 120$ \\
\hline Purchase cost (per unit) & $\$ 50$ & $\$ 60$ & $\$ 70$ & $\$ 80$ & $\$ 90$ \\
\hline
\end{tabular}

F Company has $\$ 10,000$ each year of cash operating expenses, and it has depreciation expense and interest expense as discussed above. All purchases and sales were made for cash. F Company used the FIFO assumption to account for its inventory transactions. F Company's tax rate was 35 percent.

\section{Company}

L Company is the twin company to F Company: It was founded on the same day, it received the same initial investment from its owners, and during the five-year period 20X1 to $20 \mathrm{X} 5$ it engaged in exactly the same transactions as did F Company. L Company purchased the same quantities of inventory at the same costs, and it made the same sales at the same prices. Like F Company, L Company made all of its purchases and all of its sales for cash. L Company also had the same 35 percent tax rate as did F Company. The only difference between the two companies is that L Company accounted for its inventory transactions using LIFO rather than the FIFO.

\section{QUESTIONS}

1. Prepare the following financial statements for each company for each of the five years, $20 \mathrm{X} 1$ to $20 \mathrm{X} 5$ :

- Annual income statement.

- Annual cash flow statement.

- Year-end-balance sheet.

Prepare the cash flow statements twice, once computing cash from operating activities using the indirect approach and once using the direct approach.

2. Comment on the differences between the reported results for F Company and the reported results for $\mathrm{L}$ Company over the five years. Indicate which company you believe performed better. Which company's stock would you prefer to own at December 31, 20X5? Explain your answers.

3. What, if anything, do these results tell you about the relative ability of the indirect approach versus the direct approach to explain the differences in the cash flows for these two companies? Explain your answers.

4. What, if anything, do these results tell you about the differences between LIFO and FIFO in terms of the quality of earnings for the reported net income? Explain your answers.

5. In recent years there has been a concerted effort to converge U.S. GAAP with International Financial Reporting Standards (IFRS.) One of the remaining differences between U.S. GAAP and IFRS is the question of how to value inventories in the balance sheet. Although a substantial number of U.S. corporations choose to value their inventories at LIFO, IFRS does not permit LIFO for financial reporting purposes. (International Accounting Standards Board, 2003) What would be the consequences for U.S. companies that are currently using LIFO if convergence of U.S. GAAP with IFRS were to result in LIFO being disallowed in the U.S. for financial reporting purposes? Illustrate your answer by preparing a pro forma $20 \mathrm{X} 5$ income statement for L Company, based on the assumption that L Company changed from LIFO to FIFO during $20 \mathrm{X} 5$. 


\section{PROPOSED SOLUTIONS}

\section{Answers to Question 1}

The answers to the various parts of question one are presented in Tables 2 through 9. Tables 2 through 5 contain the financial statements for F Company, while Tables 6 through 9 contain the financial statements for L Company. Each Income Statement contains a separate schedule of cost of goods sold to clarify that computation.

Table 2. Annual Income Statements for F Company

\begin{tabular}{|c|c|c|c|c|c|}
\hline & $20 \times 1$ & $20 \times 2$ & $20 \times 3$ & $20 \times 4$ & $20 \times 5$ \\
\hline Net Sales & $\$ 40,000$ & $\$ 45,000$ & $\$ 50,000$ & $\$ 55,000$ & $\$ 60,000$ \\
\hline \multicolumn{6}{|l|}{ Expenses } \\
\hline Cost of Goods Sold & $\$ 24,000$ & $\$ 29,000$ & $\$ 34,000$ & $\$ 39,000$ & $\$ 44,000$ \\
\hline Cash Operating Expenses & 10,000 & 10,000 & 10,000 & 10,000 & 10,000 \\
\hline Depreciation & 3,000 & 3,000 & 3,000 & 3,000 & 3,000 \\
\hline Interest & 1,500 & 1,500 & 1,500 & 1,500 & 1,500 \\
\hline Total Expenses & 38,500 & 43,500 & 48,500 & 53,500 & 58,500 \\
\hline Income Before Tax & 1,500 & 1,500 & 1,500 & 1,500 & 1,500 \\
\hline Income Tax Expense & 525 & 525 & 525 & 525 & 525 \\
\hline Net Income & $\$ 975$ & $\$ 975$ & $\$ 975$ & $\$ 975$ & $\$ 975$ \\
\hline \multicolumn{6}{|l|}{ Schedule of Cost of Goods Sold } \\
\hline Beginning Inventory & $\$ 4,000$ & $\$ 5,000$ & $\$ 6,000$ & $\$ 7,000$ & $\$ 8,000$ \\
\hline Inventory Purchases & 25,000 & 30,000 & 35,000 & 40,000 & 45,000 \\
\hline Cost of Goods Available for Sale & 29,000 & 35,000 & 41,000 & 47,000 & 53,000 \\
\hline Ending Inventory & $(5,000)$ & $(6,000)$ & $(7,000)$ & $(8,000)$ & $(9,000)$ \\
\hline Cost of Goods Sold & $\$ 24,000$ & $\$ 29,000$ & $\$ 34,000$ & $\$ 39,000$ & $\$ 44,000$ \\
\hline
\end{tabular}

Table 3. Annual Cash Flow Statements for F Company (Indirect Approach)

\begin{tabular}{|c|c|c|c|c|c|}
\hline & $20 \times 1$ & $20 \times 2$ & $20 \times 3$ & $20 \times 4$ & $20 \times 5$ \\
\hline \multicolumn{6}{|l|}{ Operating Activities } \\
\hline Net Income & $\$ 975$ & $\$ 975$ & $\$ 975$ & $\$ 975$ & $\$ 975$ \\
\hline \multicolumn{6}{|l|}{ Adjustments: } \\
\hline Depreciation & 3,000 & 3,000 & 3,000 & 3,000 & 3,000 \\
\hline Increase in inventory & $(1,000)$ & $(1,000)$ & $(1,000)$ & $(1,000)$ & $(1,000)$ \\
\hline Cash from Operating Activities & 2,975 & 2,975 & 2,975 & 2,975 & 2,975 \\
\hline Cash from Investing Activities & 0 & 0 & 0 & 0 & 0 \\
\hline Cash from Financing Activities & 0 & 0 & 0 & 0 & 0 \\
\hline Net Increase in Cash & $\$ 2,975$ & $\$ 2,975$ & $\$ 2,975$ & $\$ 2,975$ & $\$ 2,975$ \\
\hline Beginning Cash Balance & 0 & 2,975 & 5,950 & 8,925 & 11,900 \\
\hline Ending Cash Balance & $\$ 2,975$ & $\$ 5,950$ & $\$ 8,925$ & $\$ 11,900$ & $\$ 14,875$ \\
\hline \multicolumn{6}{|l|}{ Non-cash Transactions } \\
\hline Stock issued for inventory & $\$ 4,000$ & $\$ 0$ & $\$ 0$ & $\$ 0$ & $\$ 0$ \\
\hline Long-term note issued for equipment & $\$ 15,000$ & $\$ 0$ & $\$ 0$ & $\$ \$ 0$ & $\$ 0$ \\
\hline
\end{tabular}


Table 4. Annual Cash Flow Statements for F Company (Direct Approach)

\begin{tabular}{|c|c|c|c|c|c|}
\hline & $20 \times 1$ & $20 \times 2$ & $20 \times 3$ & $20 \times 4$ & $20 \times 5$ \\
\hline \multicolumn{6}{|l|}{ Operating Activities } \\
\hline Cash Collected from Customers & $\$ 40,000$ & $\$ 45,000$ & $\$ 50,000$ & $\$ 55,000$ & $\$ 60,000$ \\
\hline \multicolumn{6}{|l|}{ Cash Paid for: } \\
\hline Inventory Purchases & 25,000 & 30,000 & 35,000 & 40,000 & 45,000 \\
\hline Operating Expenses & 10,000 & 10,000 & 10,000 & 10,000 & 10,000 \\
\hline Interest & 1,500 & 1,500 & 1,500 & 1,500 & 1,500 \\
\hline Income Taxes & 525 & 525 & 525 & 525 & 525 \\
\hline Total Paid & 37,025 & 42,025 & 47,025 & 52,025 & 57,025 \\
\hline Cash from Operating Activities & 2,975 & 2,975 & 2,975 & 2,975 & 2,975 \\
\hline Cash from Investing Activities & 0 & 0 & 0 & 0 & 0 \\
\hline Cash from Financing Activities & 0 & 0 & 0 & 0 & 0 \\
\hline Net Increase in Cash & $\$ 2,975$ & $\$ 2,975$ & $\$ 2,975$ & $\$ 2,975$ & $\$ 2,975$ \\
\hline Beginning Cash Balance & 0 & 2,975 & 5,950 & 8,925 & 11,900 \\
\hline Ending Cash Balance & $\$ 2,975$ & $\$ 5,950$ & $\$ 8,925$ & $\$ 11,900$ & $\$ 14,875$ \\
\hline \multicolumn{6}{|l|}{ Non-cash Transactions } \\
\hline Stock issued for inventory & $\$ 4,000$ & $\$ 0$ & $\$ 0$ & $\$ 0$ & $\$ 0$ \\
\hline Long-term note issued for equipment & $\$ 15,000$ & $\$ 00$ & $\$ \$ 0$ & $\$ \$ 0$ & $\$ \$ 0$ \\
\hline
\end{tabular}

Table 5. Balance Sheets for F Company

\begin{tabular}{l|r|r|r|r|r}
\hline & $\mathbf{2 0 X 1}$ & $\mathbf{2 0 X 2}$ & $\mathbf{2 0 X 3}$ & $\mathbf{2 0 X 4}$ & $\mathbf{2 0 X 5}$ \\
\hline Assets & & & & & \\
\hline Cash & $\$ 2,975$ & $\$ 5,950$ & $\$ 8,925$ & $\$ 11,900$ & $\$ 14,875$ \\
\hline Inventory & 5,000 & 6,000 & 7,000 & 8,000 & 9,000 \\
\hline Plant assets (net) & 12,000 & 9,000 & 6,000 & 3,000 & 0 \\
\hline Total & $\$ 19,975$ & $\$ 20,950$ & $\$ 21,925$ & $\$ 22,900$ & $\$ 23,875$ \\
\hline
\end{tabular}

\section{Liabilities and Equity}

\begin{tabular}{|c|c|c|c|c|c|}
\hline Long-term Note - Current Maturity & $\$ 0$ & $\$ 0$ & $\$ 0$ & $\$ 0$ & $\$ 15,000$ \\
\hline Long-term Note - Non-Current & 15,000 & 15,000 & 15,000 & 15,000 & 0 \\
\hline Common Stock & 4,000 & 4,000 & 4,000 & 4,000 & 4,000 \\
\hline Retained Earnings & 975 & 1,950 & 2,925 & 3,900 & 4,875 \\
\hline Total & $\$ 19,975$ & $\$ 20,950$ & $\$ 21,925$ & $\$ 22,900$ & $\$ 23,875$ \\
\hline
\end{tabular}

Table 6. Annual Income Statements for L Company

\begin{tabular}{|c|c|c|c|c|c|}
\hline & $20 \times 1$ & $20 \times 2$ & $20 \times 3$ & $20 \times 4$ & $20 \times 5$ \\
\hline Net Sales & $\$ 40,000$ & $\$ 45,000$ & $\$ 50,000$ & $\$ 55,000$ & $\$ 60,000$ \\
\hline \multicolumn{6}{|l|}{ Expenses } \\
\hline Cost of Goods Sold & $\$ 25,000$ & $\$ 30,000$ & $\$ 35,000$ & $\$ 40,000$ & $\$ 45,000$ \\
\hline Cash Operating Expenses & 10,000 & 10,000 & 10,000 & 10,000 & 10,000 \\
\hline Depreciation & 3,000 & 3,000 & 3,000 & 3,000 & 3,000 \\
\hline Interest & 1,500 & 1,500 & 1,500 & 1,500 & 1,500 \\
\hline Total Expenses & 39,500 & 44,500 & 49,500 & 54,500 & 59,500 \\
\hline Income Before Tax & 500 & 500 & 500 & 500 & 500 \\
\hline Income Tax Expense & 175 & 175 & 175 & 175 & 175 \\
\hline Net Income & $\$ 325$ & $\$ 325$ & $\$ 325$ & $\$ 325$ & $\$ 325$ \\
\hline \multicolumn{6}{|l|}{ Schedule of Cost of Goods Sold } \\
\hline Beginning Inventory & $\$ 4,000$ & $\$ 4,000$ & $\$ 4,000$ & $\$ 4,000$ & $\$ 4,000$ \\
\hline Inventory Purchases & 25,000 & 30,000 & 35,000 & 40,000 & 45,000 \\
\hline Cost of Goods Available for Sale & 29,000 & 34,000 & 39,000 & 44,000 & 49,000 \\
\hline Ending Inventory & $(4,000)$ & $(4,000)$ & $(4,000)$ & $(4,000)$ & $(4,000)$ \\
\hline Cost of Goods Sold & $\$ 25,000$ & $\$ 30,000$ & $\$ 35,000$ & $\$ 40,000$ & $\$ 45,000$ \\
\hline
\end{tabular}


Table 7. Annual Cash Flow Statements for L Company (Indirect Approach)

\begin{tabular}{|c|c|c|c|c|c|}
\hline & $20 \times 1$ & $20 \times 2$ & $20 \times 3$ & $20 \times 4$ & $20 \times 5$ \\
\hline \multicolumn{6}{|l|}{ Operating Activities } \\
\hline Net Income & $\$ 325$ & $\$ 325$ & $\$ 325$ & $\$ 325$ & $\$ 325$ \\
\hline \multicolumn{6}{|l|}{ Adjustments: } \\
\hline Depreciation & 3,000 & 3,000 & 3,000 & 3,000 & 3,000 \\
\hline Cash from Operating Activities & 3,325 & 3,325 & 3,325 & 3,325 & 3,325 \\
\hline Cash from Investing Activities & 0 & 0 & 0 & 0 & 0 \\
\hline Cash from Financing Activities & 0 & 0 & 0 & 0 & 0 \\
\hline Net Increase in Cash & 3,325 & 3,325 & 3,325 & 3,325 & 3,325 \\
\hline Beginning Cash Balance & 0 & 3,325 & 6,650 & 9,975 & 13,300 \\
\hline Ending Cash Balance & $\$ 3,325$ & $\$ 6,650$ & $\$ 9,975$ & $\$ 13,300$ & $\$ 16,625$ \\
\hline \multicolumn{6}{|l|}{ Non-cash Transactions } \\
\hline Stock issued for inventory & $\$ 4,000$ & $\$ 0$ & $\$ 0$ & $\$ 0$ & $\$ 0$ \\
\hline Long-term note issued for equipment & $\$ 15,000$ & $\$ 0$ & $\$ 0$ & $\$ 00$ & $\$ 0$ \\
\hline
\end{tabular}

Table 8. Annual Cash Flow Statements for L Company (Direct Approach)

\begin{tabular}{|c|c|c|c|c|c|}
\hline & $20 \times 1$ & $20 \times 2$ & $20 \times 3$ & $20 \times 4$ & $20 \times 5$ \\
\hline \multicolumn{6}{|l|}{ Operating Activities } \\
\hline Cash Collected from Customers & $\$ 40,000$ & $\$ 45,000$ & $\$ 50,000$ & $\$ 55,000$ & $\$ 60,000$ \\
\hline \multicolumn{6}{|l|}{ Cash Paid for: } \\
\hline Inventory Purchases & 25,000 & 30,000 & 35,000 & 40,000 & 45,000 \\
\hline Operating Expenses & 10,000 & 10,000 & 10,000 & 10,000 & 10,000 \\
\hline Interest & 1,500 & 1,500 & 1,500 & 1,500 & 1,500 \\
\hline Income Taxes & 175 & 175 & 175 & 175 & 175 \\
\hline Total Paid & 36,675 & 41,675 & 46,675 & 51,675 & 56,675 \\
\hline Cash from Operating Activities & 3,325 & 3,325 & 3,325 & 3,325 & 3,325 \\
\hline Cash from Investing Activities & 0 & 0 & 0 & 0 & 0 \\
\hline Cash from Financing Activities & 0 & 0 & 0 & 0 & 0 \\
\hline Net Increase in Cash & 3,325 & 3,325 & 3,325 & 3,325 & 3,325 \\
\hline Beginning Cash Balance & 0 & 3,325 & 6,650 & 9,975 & 13,300 \\
\hline Ending Cash Balance & $\$ 3,325$ & $\$ 6,650$ & $\$ 9,975$ & $\$ 13,300$ & $\$ 16,625$ \\
\hline \multicolumn{6}{|l|}{ Non-cash Transactions } \\
\hline Stock issued for inventory & $\$ 4,000$ & $\$ 0$ & $\$ 0$ & $\$ 0$ & $\$ 0$ \\
\hline Long-term note issued for equipment & $\$ 15,000$ & $\$ \$ 0$ & $\$ \$ 0$ & 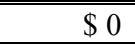 & $\$ \$ 0$ \\
\hline
\end{tabular}

Table 9. Balance Sheets for L Company

\begin{tabular}{l|r|r|r|r|r}
\hline & $\mathbf{2 0 X 1}$ & $\mathbf{2 0 X 2}$ & $\mathbf{2 0 X 3}$ & $\mathbf{2 0 X 4}$ & $\mathbf{2 0 X 5}$ \\
\hline Assets & & & & & \\
\hline Cash & $\$ 3,325$ & $\$ 6,650$ & $\$ 9,975$ & $\$ 13,300$ & $\$ 16,625$ \\
\hline Inventory & 4,000 & 4,000 & 4,000 & 4,000 & 4,000 \\
\hline Plant assets (net) & 12,000 & 9,000 & 6,000 & 3,000 & 0 \\
\hline Total & $\$ 19,325$ & $\$ 19,650$ & $\$ 19,975$ & $\$ 20,300$ & $\$ 20,625$ \\
\hline
\end{tabular}

\section{Liabilities and Equity}

\begin{tabular}{|c|c|c|c|c|c|}
\hline Long-term Note - Current Maturity & $\$ 0$ & $\$ 0$ & $\$ 0$ & $\$ 0$ & $\$ 15,000$ \\
\hline Long-term Note - Non-Current & 15,000 & 15,000 & 15,000 & 15,000 & 0 \\
\hline Common Stock & 4,000 & 4,000 & 4,000 & 4,000 & 4,000 \\
\hline Retained Earnings & 325 & 650 & 975 & 1,300 & 1,625 \\
\hline Total & $\$ 19,325$ & $\$ 19,650$ & $\$ 19,975$ & $\$ 20,300$ & $\$ 20,625$ \\
\hline
\end{tabular}




\section{Answers to Question 2.}

Individual students' answers may vary, but here are important points that all answers should address:

- F Company's cost of goods sold has consistently been lower than L Company's, while its income tax expense and net income have both been higher. At the end of the five years, F Company has higher balances in inventory and retained earnings. On the other hand, L Company's operating cash flow has consistently been higher than F Company's, and at the end of the five years L Company has more cash than F Company.

- Income, and particularly operating income, is a conventional indicator of a company's operating performance. Based on F Company's higher income, higher total assets and higher retained earnings, students normally judge that F Company has performed better over the period.

An excellent answer might also include the following:

- Income is not the only valid indicator of operating performance. In this case, each company is obligated to make a $\$ 15,000$ cash payment on January 1, 20X6, to liquidate a long-term note that matures on that date. At December 31,20X5, F Company does not have sufficient cash to make that payment. F Company is insolvent, and its ability to continue as a going concern may even be in question. L Company does have sufficient cash to make that payment, and there is no reason to question its ability to continue as a going concern. F Company's insolvency and the related going concern issues strongly suggest that F Company has not performed well over these five years, and it certainly has not performed as well as L Company.

\section{Answers to Question 3.}

Individual students' answers may vary, but here are important points that all answers should address:

- The indirect approach focuses on differences between income and operating cash flows. According to the indirect approach cash flow statement, the sole difference between F Company and L Company is the year-by-year increase in the value of F Company's inventory. F Company's lower cash flow is the result of F Company's investing additional cash in increasing its inventory.

- The direct approach focuses on the specific activities that created cash inflows and cash outflows. According to the direct approach cash flow statement, the sole difference between the two companies is that F Company paid more for income taxes each year than did L Company.

An excellent answer might also include the following:

- The indirect version of the cash flow statement indicates that F Company's lower cash flows were associated with the growth in F Company's inventories over time. That explanation is factually incorrect. Neither company's inventory changed at all, at least with respect to the physical quantity of inventory on hand, over the five-year period. (Refer to Table 1.) Furthermore, the total cost of the inventory purchased each year was exactly the same for both companies. F Company actually did not invest more cash in its inventories than L Company did. The only difference between the two companies' inventories is that $\mathrm{F}$ Company assigned a higher cost per unit (FIFO cost rather than LIFO cost) to the units on hand at the end of each year. That was a non-cash related choice of valuation methods, and it was not associated with any additional cash payments made by F Company for inventory purchases.

- The direct version of the cash flow statement indicates that F Company's lower cash flows were associated with the additional income taxes that $\mathrm{F}$ Company had to pay each year. That explanation is factually correct. By reporting its inventories at FIFO, F Company has chosen to report higher annual net income than L Company. But that choice also forced F Company to pay the income tax on that larger income. It was those higher tax payments that reduced F Company's annual net cash flow. 
- In this particular case, the direct approach has provided better, more useful information than has the indirect approach.

\section{Answers to Question 4}

Individual students' answers may vary, but here are important points that all answers should address:

- There should be some discussion of the concept of Quality of Earnings and the characteristics which high-quality earnings possess. Be sure the student is able to distinguish between quality of financial reporting and quality of earnings. Quality of financial reporting simply asks whether or not the financial statements correctly apply the specific accounting principles that the company has chosen. In this case Company $\mathrm{F}$ and Company $\mathrm{L}$ both have equally good quality of financial reporting. Quality of earnings is a much more complex concept, and analyzing it is more difficult. Some characteristics commonly cited as indicators of higher quality earnings are these: High quality earnings are repeatable and controllable (the result of primary operating activities rather than external events not under the company's control), and they are also bankable (related to foreseeable cash inflows and capable of being distributed as dividends.)

- F Company's earnings are higher, but they are only higher because of inflation: If there had been no inflation, F Company and L Company would have been the same, and if inflation were to cease in the future their earnings would be the same from that point forward. Since inflation is exogenous to the firm - something the firm does not control and cannot voluntarily repeat in the future - then to the extent that F Company's earnings are attributable to inflation, they would be considered lower-quality.

An excellent answer might also include the following:

- Although F Company's earnings are higher than L Company's earnings, F Company's cash flows are lower. The conclusion is that the correlation between F Company's earnings and its cash flows is not as high as the correlation between L Company's earnings and its cash flows. A lower correlation between income and cash flows is an indicator of lower quality earnings, while a higher correlation indicates higher quality earnings.

\section{Answers to Question 5}

Table 10 illustrates how changing from LIFO to FIFO at the end of 20X5 would cause L Company's pretax income to increase by $\$ 5,000$. As a result, L Company's tax liability for $20 X 5$ would increase by $\$ 1,750$ (35 percent of $\$ 5,000$.) All of the tax benefits that L Company realized from using LIFO during the years $20 \mathrm{X} 1$ to $20 \mathrm{X} 4$ would be lost, and all of the additional taxes related to those previous years would be assessed in 20X5. Fortunately, current tax law allows L Company to seek approval from the IRS to spread those additional taxes over the four years $20 X 5$ to 20X8. Nonetheless, the requirement to make those additional tax payments will negate any advantage $\mathrm{L}$ Company accrued by using LIFO over the period 20X1 to 20X5, and as of the end of 20X5 that additional tax liability will place L Company in effectively the same financial position as F Company.

If the convergence of U.S. GAAP and IFRS were to result in the disallowance of LIFO for tax purposes, the impact on U.S. businesses would be substantial. ${ }^{1}$ To illustrate the magnitude of that impact, Jade West of The LIFO Coalition pointed out in her testimony before Congress in 2012 that "The LIFO repeal proposal in the President's FY 2013 budget is estimated to generate about \$74 Billion." (Tax Reform, 2012.) The tax effects of repealing LIFO are often cited as one reason that U.S. GAAP and IFRS may never be fully converged.

\footnotetext{
${ }^{1}$ Changes in U.S. GAAP do not affect U.S. tax law. However, 26 U.S.C. $\$ 1.472-2(\mathrm{e})$, also known as the LIFO conformity requirement, requires that if a taxpayer elects to use LIFO for federal income tax purposes, it must prove to the IRS that it uses no method other than LIFO in its determination of income, profit, or loss. Since IFRS does not permit LIFO for financial reporting purposes, convergence of U.S. GAAP with IFRS could mean that LIFO would no longer be an allowable inventory method for financial reporting. Thus, unless the LIFO conformity rule is relaxed, eliminating LIFO as a financial reporting method would in turn disallow LIFO as a tax reporting method. All companies currently using LIFO would have to change to a different method.
} 
Table 10. Pro Forma Income Statement for L Company

\begin{tabular}{lc}
\hline & $\mathbf{2 0 X 5}$ \\
\hline Net Sales & $\$ 60,000$ \\
\hline Expenses & \\
\hline Cost of Goods Sold & $\$ 40,000$ \\
\hline Cash Operating Expenses & 10,000 \\
\hline Depreciation & 3,000 \\
\hline Interest & 1,500 \\
\hline Total Expenses & 54,500 \\
\hline Income Before Tax & 5,500 \\
\hline Income Tax Expense & 1,925 \\
\hline Net Income & $\$ 3,575$ \\
\hline & \\
Schedule of Cost of Goods Sold & $\$ 4,000$ \\
\hline Beginning Inventory (valued at LIFO) & \\
\hline Inventory Purchases & 45,000 \\
\hline Cost of Goods Available for Sale & 49,000 \\
\hline Ending Inventory (valued at FIFO) & $(9,000)$ \\
\hline Cost of Goods Sold & $\$ 40,000$ \\
\hline
\end{tabular}

TEACHING NOTES

One important feature of the FIFO-LIFO Case is its adaptability to support a variety of learning outcomes in different courses. This flexibility results from making the questions posed in the case as independent of each other as possible. That independence allows a professor to select only the questions that support the learning outcomes for that professor's specific course. The teaching notes discuss in detail possible course applications and uses of this case.

The only exception to that idea of the questions being independent of each other occurs in classes where financial statement preparation is not an important learning outcome. Students will need to have access to the financial statements for both companies as a basis for answering the other questions, so in classes where the students are not assigned to prepare the statements it would be appropriate to hand out copies of the completed financial statements along with the case.

Here is an overview of some of the courses where the case could be used, along with tips for how to use the case in each of these courses.

\section{Intermediate Accounting (Undergraduate courses, usually focused on accounting majors)}

The recommended assignments for Intermediate Accounting students would be questions 1 and 2. Courses in the Intermediate Accounting sequence generally tend to be heavily procedurally-oriented, emphasizing analysis and recording of transactions and preparation of financial statements in good form. The learning outcomes for these courses tend to be more mechanical than conceptual, and the material is dense and complex. Feedback received from students in the last course in this sequence indicated that, after looking at so many reporting details related to so many different types of business activities, many students felt that they had simply forgotten a lot of the basics. Although very few students indicated that they actually enjoyed answering Question 1 - preparing the financial statements for both companies - most of them felt that it provided a useful and timely refresher on this material.

The suggested teaching strategy is to assign question 1 as an out-of-class assignment. The students can hand it in so that the assignment can be checked and the numbers in the financial statements verified. After that is done, question 2 could be assigned for class discussion purposes, either as an individual assignment or a group assignment.

${ }^{2}$ For financial reporting purposes this change would have been handled retrospectively: Beginning inventory would have been revalued from $\$ 4,000$ to $\$ 8,000$ as a prior period adjustment of retained earnings, and only the current year impact on cost of goods sold would have appeared in the income statement. The income statement shown here was designed to emphasize the tax impact of this change (all of which occurs in 20X5) rather than to illustrate the correct method of reporting this change in L Company's 20X5 financial statements. 
- The specific learning outcomes supported by question 1, classified in terms of Bloom's Taxonomy (Bloom et al., 1956), would include the following: Analyze events. (Analysis.) Apply GAAP rules of recognition, measurement, etc. to decide when and how these events should appear in the financial statements. (Application.) Use the resulting information to prepare financial statements. (Synthesis.)

- Question 2, which asks the students to make a judgment regarding which company has performed better over the period, is a useful follow-up to question 1 because it requires the students to go beyond simple preparation of financial statements to interpreting the information reported in those statements. As such, it requires the students to engage in some of the higher-order thinking skills that CPA firms and other employers value highly. The specific learning outcomes supported by question 2 would include the following: Decide on an appropriate metric to rely upon to assess performance and justify that choice. (Evaluation.) Apply that metric to the facts of the case to assess which company has performed better and explain why. (Analysis, Application, and Evaluation).

\section{Financial Accounting or Financial Statement Analysis (General Management MBA)}

The learning outcomes for this type of course would not include being able to prepare financial statements. Instead, the outcomes generally relate to being able to understand, interpret, and apply the information contained in those statements. The recommended assignments for this type of class would be questions 2, 3, and 4. Question 1 would not normally be assigned in this type of course. However, the students need to have the finished financial statements available in order to answer the other questions. Consequently, the best strategy would be to hand out the financial statements along with the case, and then assign questions 2,3 , and 4 for the students to answer,

As an overall teaching strategy, it is recommended to assign the students to review the financial statements that were handed out and then prepare answers to questions 2,3 , and 4 to prepare for a class discussion. The learning outcomes associated with those questions are as follows:

- Question 2: Which firm has performed better? Why? These questions require the students to analyze the information reported in the financial statements (Analytical thinking) and evaluate each company's performance. (Evaluation.) Implicitly these questions also require the students to consider the question of what metric (or metrics) would be relevant as benchmarks for evaluating a company's performance. (Evaluation.) It would be a useful part of the class discussion to ask the class to decide which metrics should be used.

- Question 3: Which form of the cash flow statement provides better information about the reasons why the cash flows are different? This question requires the students to analyze the content of each statement from a conceptual rather than a mechanical point of view: What does each one report, and what does each one not report? (Analytical thinking.) It also requires a comparison of the reported information with the underlying facts, and it requires an evaluation of which one of the two statements does a better job of explaining those facts. (Analytical thinking and Evaluation.) Finally, it also requires the class to come to a decision about what constitutes "better" information. (Evaluation.)

- Question 4: Which method - FIFO or LIFO - results in the company reporting higher-quality earnings? One way to address this question would be to assign the class the task of finding out what is meant by "quality of earnings" and identifying the characteristics that are considered to be indicators of high-quality earnings. Open the class with a discussion of earnings quality, with the purpose of gaining some sort of consensus regarding what they believe constitutes high quality earnings. After that discussion, have the class evaluate L Company's earnings and F Company's earnings, and have them decide which company's earnings are higher quality. (Analysis, Synthesis, and Evaluation.)

\section{Accounting Theory (Senior-level Undergraduate or Graduate Accounting Students)}

The typical learning outcomes for an accounting theory class would be that students will be able to examine accounting issues from a theoretical rather than a purely mechanical perspective. Accounting theory is another course where question 1 - preparation of financial statements - would probably not be an appropriate assignment. 
Consistent with that idea, this is a course where it would be appropriate to hand out the financial statements to the students along with the case.

Depending on available time and other course-specific objectives, the professor could assign any or all of the following questions: 2, 3, 4 and 5. The overall teaching strategy for questions 2, 3, and 4 would be very similar to the strategy outlined above for the MBA Financial Accounting or MBA Financial Statement Analysis course, and the discussion outlines would also be similar. The major difference would be the professor's expectations about the quality of the answers.

Question 5 requires the students (probably for the first time) to confront the reality that setting accounting standards is not just an abstract exercise in professional preference or accounting theory. Choices of accounting principles can have real economic impacts on specific companies or specific industry sectors, and those impacts will often cause the affected parties to attempt to exert political pressure on the standards-setting body. IFRS convergence, which could possibly spell the end of LIFO, is an example of just such a politically-charged change.

- Question 5: If convergence of U.S. GAAP with IFRS were to lead to the disallowance of LIFO as a financial reporting method, what might be the consequences for U.S. companies? One point that needs to be included in this discussion is this: Changes in U.S. GAAP normally do not have tax effects. However, the LIFO conformity rule means that this change will have tax (and therefore cash flow) effects. A useful follow-up question for this discussion might be this: If IFRS convergence does occur and LIFO actually is disallowed for financial reporting purposes, should the LIFO conformity rule be relaxed? If LIFO is disallowed but the LIFO conformity rule remains, that will place a great tax burden on many of the largest U.S. companies, perhaps even causing substantial damage to the U.S. economy. On the other hand, if the LIFO conformity rule is relaxed, the additional taxes would effectively be forgiven. The result might be a huge public outcry about the government giving major tax relief to highly profitable companies in a time of federal budget deficits. This discussion might be useful exercise for helping the students understand the reality of the political pressures accounting standards-setters can face.

\section{AUTHOR BIOGRAPHIES}

A. Bruce Caster, PhD, CPA, CGMA (acaster@siena.edu) is an Associate Professor of Accounting at Siena College in Loudonville, NY. He previously held teaching positions at Valdosta State University and Utica College, and he has taught financial accounting, managerial accounting, accounting information systems, auditing, and financial accounting theory. Dr. Caster has published papers in the areas of financial accounting, accounting education, corporate governance, and ethics. He is a member of the AICPA, the Georgia Society of CPAs, the AAA, and the ACFE. (Contact author.)

Wanda K. Causseaux. DBA, CMA (wcausseaux@siena.edu) is an Assistant Professor of Accounting at Siena College in Loudonville, NY, where she teaches financial accounting, managerial accounting, cost accounting, and fraud and forensic accounting. Dr. Causseaux has published papers in the areas of financial accounting, accounting education, corporate governance, and ethics. She is a member of the IMA, the AAA, and the ACFE. Prior to becoming a professor, Dr. Causseaux spent 14 years in manufacturing and in commercial banking.

\section{REFERENCES}

Bloom, B. S., Engelhart, M. D., Furst, E. J., \& Hill, W. H.; Krathwohl, D. R. (1956). Taxonomy of educational objectives: The classification of educational goals. Handbook I: Cognitive domain. New York: David McKay Company.

International Accounting Standards Board (2003). International financial reporting standards (IFRS's): Including international accounting standards (IAS's) and interpretations. London: International Accounting Standards Board.

Tax Reform and the U.S. Manufacturing Sector: Hearings before the Ways and Means Committee, House of Representatives, 112th Cong. (2012) (Testimony of Jade West). Retrieved from http://waysandmeans.house.gov/UploadedFiles/The_LIFO_Coalition.pdf. 